\title{
The Effect of Using Blogs on Developing Some Functional Writing Skills of Second Year Secondary School Students in Beni-Suef.
}

\section{$\underline{\text { Abstract }}$}

\section{By Dr. Mukhtar Abd Elfattah Abd Elmaksoud,}

The use of the internet, as a powerful communication tool has spread throughout the world since it was discovered. It has become as one of the most important means of communication among individuals, peoples and nations. Functional writing often turns a complex subject into something that is more understandable to the reader. Teachers can help students master this type of writing by assigning various functional writing activities. After dealing with the review of literature, observation and interviews, the researcher stated the problem of the study. Objectives, importance, questions, hypotheses, tools, delimitations, sample, terms and references of the study were mentioned. Questions of the study were:(1) What are the functional writing skills that are important to second year secondary school students?(2)What is the effect of blogs on developing each one of the functional writing skills which are important to second year secondary school students?(3)What is the effect of blogs on developing the overall functional writing skills which are important to second year secondary school students? Participants were chosen randomly from Beni-Suef Secondary School for Girls Procedures included administering the questionnaire to senior teachers after achieving validity and reliability. According to the results of the questionnaire, the researcher started designing a program to help students develop the functional writing skills. The skills were: Punctuation, Book Reviews, Business Letter, Event Posters, Community Banners, and Giving pieces of Advice. Before administering the pre-test, the researcher submitted it to some juries for validity, then reliability was achieved. Students' scores were low. Afterwards, the researcher started teaching the program to train students through the use of blogs. Students took the instructional materials. The students were post tested. The findings revealed that using blogs had a positive effect on students' functional writing skills.

Keywords:: Blogs, , Writing, Functional Writing,

\section{Introduction}

The use of the internet, as a powerful communication tool has spread through out the world since it was discovered. It has become as one of the most important means of communication among individuals, peoples and nations. The internet has broadened horizons and scope of life. Advertising on web pages, e-mail, instant chat, video conferencing and many other ways of communicating has evolved through out the years. People can $\log$ in and instantly see which of friends are online. A person 
can send an instant message, e-mail, chat or make a video call. In addition, a person can see colleagues and discuss issues with each other

Cary, (2013 1-2) pointed out that the Internet helps users with multiple means of communicating. Users may communicate with friends, colleagues, news reporters, editors and even any strangers. Today there are more ways to reach out to people who were traditionally difficult to contact. As technology advances, the means of Internet communications become increasingly convenient and varied. Members of social networking sites are able to send messages, comments, links, articles and pictures to other members of the site. Communication is not just between the sender and receiver, it is also available to other members who have access to browse your site. These other members may also make comments. This type of relationship is known as an Internet community. Skype.com is a website dedicated to providing online phone calls to other Skype members. This type of communication is known as Skypeto-Skype calling. E-mail does not only allows a person to communicate with other email users, but it also is a way of receiving, , newsletters, coupons, daily inspirational quotes and job postings. It is known that registered users are able to save drafts and past important e-mails for future reference.

Blogging is a writer's way of expressing his thoughts, ideas, and social and political views online. Bloggers communicate to readers, who in turn make comments and send their links to other readers. Some bloggers gain notoriety through building a devout group of readers. Once bloggers have a following, they may be contacted by sponsors or they may propose sponsorship to interested companies.

\section{The Difference between Vlogs and Blogs}

Cary added that vlogs are the same concept as blogs, except vlogs are digitally recorded. You can create a vlog on a digital video camera, digital camera, or cell phone. Video can then be uploaded onto computer and shared with viewers.

Online forums or message boards are an interesting way for participants to express their knowledge or views of a particular subject. Participants may speak, for example, on issues like new political agendas, their favorite sports teams or discuss their concerns about new technology. Message boards range from home improvement to medical experiences and procedures.

Readers of news articles can communicate with the public, news reporters and editors by expressing their points of view of online articles. 
Other readers may make comments about the article or the previous comments about the article. Comments about comments comprise what is known as a thread.

\section{Functional Writing}

Functional writing needs to be clear in meaning and follow all writing conventions. Functional writing skills are as significant as thesis writing skills in that they, too, communicate meaning to a particular audience. Functional writing can be fun, serious, light or strictly informative. A good piece of functional writing communicates well and often motivates the recipient to action. Letter-writing is a functional writing activity. Invitations and thank-you notes are another. Business letters, particularly letters of complaint, are a very common form of functional writing. Event posters, community banners, resumes, applications, forms and emails -- all these are types of functional writing. Although practical in nature, functional writing is a challenge in that the content must be succinct and still get the message across.

\section{Secondary School-Age Writing Activities for Developing Functional Writing Skills}

"Every secondary student has a teacher he likes and admires. Suggest to your child that he write to that teacher and tell her why he likes her and the class so much. The teacher's choice can be past or present. This is specially good for Education Week or National Teachers Day. Another functional writing opportunity is to write a letter to the editor in response to a local editorial that was critical of youth. It is your child's job to tell the reading audience why the negatives do not apply. Job applications often have a space for writing "additional comments." Encourage your daughter to explain why she will be a kid whom the owner remembers long after her high school job has ended. " Walters, (2013:1-3)

"The real power of blogging, the great benefit in writing for a blog, goes not to the audience but rather to the writer. It is in the very act of writing, the preparation of the content the audience are going to share, that the benefit is found." (Moulton, 2008, Para. 6). Writing is a reflective process, and the creation of content a person is going to share causes him to work hard to make your thinking clear. Blogging forces the writer to think through what he or she is trying to say and to say it clearly." Cox, (2012: 1).He added that

because of the focus on "real-world" assessment and materials from both the Guidelines and Standards, students began to be introduced to 
authentic texts. As students read authentic texts; students then responded by writing original pieces in the L2. As discussed below, the Standards also encouraged integrating language and culture, rather than making the study of culture a separate component in the language classroom.

Jones(2006:7)pointed out that it is known that there is a wellestablished body of literature which focuses on computer - based technology tools, such as word processors, computer-mediated communication (CMC) tools (e-mail, bulletin boards, and chats), Web page projects, or a combination of tools. "Some of this literature examines the application of these technologies to various aspects of writing such as syntax (grammar, spelling, punctuation), content and language development, affect and motivation perspectives, current theoretical perspectives (e.g., constructivism, cognition, and metacognition), current writing pedagogy (e.g., process approach, post process, and genre), and teaching practices (error correction, feedback, peer editing, collaborative learning and writing, and solving problems). However, the research on L2 writing, particularly ESL writing, and its use of technology is still relatively limited.

It was not too long ago that people started using the Internet. A person types what he wants and sends the mail to the relevant mail address. Now there is the facility where anyone can attach files and send them to who ever he wants. He can attach files, folders, wave files, pictures and any other sort of file he can think of provided that the size and format is compatible on both ends. "Now it is also possible to encrypt e-mail messages. Once the file is encrypted it is almost impossible to be viewed by any third party. This depends according to

the level of inscription. The internet has shown new ways of communication and has actually taken communication to a whole new level. Now it is almost impossible to imagine life or communication without the internet." Bizymoms(1997:2)

\section{Micro-Skills of Writing}

Henry (2000) mentioned the micro-skills involved in writing skills. Mastery of these micro-skills helps the writer to have a good command over writing free of mistakes and errors. In the process of micro-skills the writer needs to:

1. use the script, spellings and punctuations correctly.

2. apply the accurate words to state the right tense, case and gender. 
3. make use of major components such as subject, verb and object

4. appropriately which can convey the thought of writer clearly to the reader.

5. make the text coherent to make the reader understand easily.

6. place all parts of speech properly.

7. apply the vocabulary and terminologies appropriately.

8. use the style of writing suitably to the requirements of the audience.

9. clarify the central ideas from the sustaining information.

10. avoid from jargon, slang, taboos and keep in mind the standard of language according to the mental level of the reader.

11. judge the prior knowledge of the audience about the subject."

Javed ; Juan ; Nazli, (2013: 131-132)

"Pylkkänen and McElree (2006) added that the students have to construct sentences bearing in mind grammatical coordination, appropriate lexis and correct spellings. It can be said that this is the best way of improving writing skills. Wren and Marten (2006) also narrated that the student has to construct

sentences keeping in mind grammatical synchronization and variation, not to mention using appropriate terminology and correct spellings.. The ultimate meaning of writing skill is to construct grammatically correct sentences and to communicate a meaning to the reader.

Pylkkänen and McElree (2006) pointed out that "Real life communicative writing tasks, on the other hand, are letter-writing, form filling, report writing and so on. These communicative writing tasks are rarely practiced in our language classrooms. Communicative writing should be logical and coherent. Cohesion; the grammatical or structural unity and coherence; the unity of sense or meanings are also essential for high-quality writing (Shahid, 1999). Moreover the communicative writing must have a purpose and logic. Writing can be divided into subskills like descriptive, narrative and expository writing skills (Wilcox, 2002). The style of what is written will automatically be affected by the status of the addressee, age, profession and relationship with the writer. Hywel (2003) bifurcated the sub-skills of writing such as descriptive skill (description of people, places and things), narrative skill (narrating stories, incidents, events with proper sequence in chronological order)

\section{5}


and expository skill (writing with the purpose to justify, explain, define, classify, compare and contrast).

\section{Review of Literature}

\section{Studies Conducted on Developing Writing Skills:}

Hill (2000) conducted a study to investigate students' goal orientation in a writing process workshop and how their goal orientation differed from that of a student in a classroom that primarily used didactic literacy instruction. The participants of this study were one hundred and forty eight eighth grade students, twelve students as research assistants and the researcher as a participant- observer. The study took place in North Carolina in the U.S.A. The study findings revealed that the classroom structure could facilitate students' goal orientation. In addition, students engaged in a writing workshop process classroom had the opportunity to do writing tasks that helped them have learning goal orientation. It was found that students' goal orientation was associated with reports of more intrinsic interest in and positive attitude towards language learning tasks. Implications for this study suggested that providing students with choice over their writing activities, autonomy, appropriate challenges and process versus product evaluation could encourage students to value their efforts and achieve tangible progress in writing.

Benischek et al (2001) describe a program for advancing written expression skills in the primary grades. Extensive research over the past years has shown that an emphasis on mechanics and conventions inhibits the process of writing in primary students. The targeted population consisted of first and second grade students in a middle class community, located in a suburb of Chicago, Illinois. Teachers at the targeted school reported varying amounts of time spent on writing as well as varied methods for teaching writing. The principal expressed a concern over the lack of scope and sequence in the current writing program adopted at the targeted school. These concerns were addressed using a writer's workshop format, mini-lessons, modeled writing, and limited editing and revisions. Writing samples were collected throughout the research project to assess student growth. Findings suggest that the Action Plan implemented was successful in increasing writing fluency. On four dimensions of writing fluency, both first and second grade students not only increased the amount of words written, but also elaborated on the content itself. Given this increase, students also constructed more mature wording; therefore, their writing sequence also increased. This was due 
to the many positive writing experiences in which students participated. Results show that students also expressed increased enjoyment when writing.

Kapka \& Oberman (2001) conducted a program designed to improve students' writing skills in order to improve academic achievement. The targeted population consists of third grade elementary students in two separate communities ranging from low to middle class, located in two Midwestern suburbs of a large city. Evidence for the existence of the problem includes writing samples, report card grades, state test scores, and teacher observations. A review of the solution strategies resulted in the selection of five major categories of intervention: teacher training on the writing process, parent involvement, implementation of a writing program to teach concepts/skills, use of a variety of writing strategies, and peer editing.. Post intervention data indicated an increase in students' writing skills. Students' knowledge of writing elements increased as demonstrated by documented work in the classroom setting.

Anderson et al (2003)designed a study to improve the writing skills of students in the targeted first and fifth grade classrooms in one elementary school located in a midwestern suburb. The study was designed as an action research project and was conducted by four researchers during the months of September through December 2002 with 118 participants (40 first graders, 60 fifth graders and 18 faculties). Journal writing and portfolios were selected as intervention strategies for the proposed study. To document the progress of students' writing skills, the following methods of assessment were used: a survey, observations and a document analysis. Post-intervention data indicated an increase in the quality and quantity of the students' writing. Attitudes towards writing also changed through the course of the intervention.

Muhammad ; Xiao ; Saima ( 2013). This study evaluates and assesses the students' competency in writing skills at Secondary school level in the English Language focusing five major content areas: word completion, sentence making/syntax, comprehension, tenses/ grammar and handwriting. The target population was the male and female students of grade 10 of urban and rural Secondary schools from public and private sector. Forty (40) Secondary schools of District Bahawalnagar, Pakistan were taken using stratified sampling. A sample consisting of 440 students (11 students from each school) was randomly selected using a table of random numbers. An achievement test consisting of different items was developed to assess the students' competency and capability in

\section{7}


sub-skills of writing such as word completion, sentence making/syntax, comprehension, tenses/grammar and handwriting. Mean score and standard deviation were used to analyze the students' proficiency in each sub-skill. The t-test was applied to make the comparison on the bases of gender, density and public and private sector. The overall performance of all the students was better in comprehension as compared to other subskills namely word completion, sentence making/syntax, tenses/grammar and handwriting. The analysis, based on t-value, revealed no significant difference between the performance of male and female students and the students of public and private schools, whereas there was a significant difference between the performance of urban and rural students.

\section{Commentary}

-Hill (2000) investigated students' goal orientation in a writing process workshop and how their goal orientation differed from that of a student in a classroom that primarily used didactic literacy instruction; whereas,

Benischek et al (2001) described a program for advancing written expression skills in the primary grades. Kapka \& Oberman (2001) showed a program designed to improve students' writing skills in order to improve academic achievement. Anderson et al (2003) tried to improve the writing skills of students in the targeted first and fifth grade classrooms in one elementary school. Muhammad ; Xiao ; Saima ( 2013). evaluated and assessed the students' competency in writing skills at secondary school level in the English Language. The current study deals with using blogs to investigate its effect on some functional writing skills

\section{Studies Related to Blogging and Writing}

Fessakis, et al (2008). Conducted a case study of the educational exploitation of group blogging for the implementation of a "learning by design" activity. More specifically, a group of students used a blog as a communication and information management tool in the University course of ICT-enhanced Geometry learning activities. The analysis of the designed learning activities, the blog content and log files, as well as the points of view of the students (via a questionnaire and a group interview) expressed upon completion of the activity gives significant findings supporting the researchers' initial hypotheses about the potential of blogs' educational applications. Blogs combined with a proper pedagogical approach such as "learning by design" enable teachers to offer high quality learning experiences to their students. 
Mourad, (2009) focussed on exploring the effectiveness of program based on the self-regulated strategy development of writing skills in writing-disabled secondary school students. A total of 67 students identified with LD were invited to participate. The sample was randomly divided into two groups; experimental ( $\mathrm{n}=34 ; 20$ boys and 14 girls) and control ( $\mathrm{n}=33,20$ boys, 13 girls). ANCOVA and Repeated Measures Analyses were employed for data analysis. Findings from this study indicated the effectiveness of the program employed in improving the writing performance of the students in the experimental group. Discussion: On the basis of the findings, the study advocates for the effectiveness of Self-Regulated Strategy Development (SRSD) in improving the writing performance of students in the experimental group.

Lou, et al.(2010) conducted a study to examine the effect of adopting blogging upon Chinese language composition instruction in a vocational high school in Taiwan. The researchers developed a model that utilizes blogging in Chinese language composition instruction. Forty randomly selected students from a public vocational high school served as the research participants. The experimental instruction was employed for eight weeks. The results of the study were as follows: (1) The instructional model of utilizing blogging in Chinese language composition in a vocational high school can be successfully implemented with positive outcomes; (2) Utilizing blogging in Chinese language composition instruction can positively enhance students' composition learning; (3) The participants possessed a positive attitude toward the instructional model of utilizing blogging in Chinese language composition instruction, and the majority of participants reported feeling positively about the overall design of the blog, the teaching materials, and their own achievement in learning composition; and (4) The instructor-student interaction was positive.

Anderson,(2010) compared between blogging and computerized journaling as effective tools for writing skill development; The purpose of the study was to discover if there was a significant difference between students that blog and students who use journals on the development of specific writing skills. In this quantitative, quasi-experimental study, data were gathered using a pretest-posttest design using a convenience sample of 70 high school freshmen in a small school in a southern US state. A rubric was used to score a writing sample from each student before and after treatment, and significance was measured using Kruskal-Wallis, 
Friedman, and the Wilcoxon tests. Results indicated no significant difference between the overall writing scores of the students that blogged and the students' computerized journaling.

$\mathrm{Wu}$, ; $\mathrm{Wu},(2011)$ attempted to discover learners' perceptions on the use of blogs for EFL (English as a foreign language) learning. Participants were 49 first-year university students from Southern Taiwan and were divided into ten groups in the study. Students in a group read the articles posted in the teacher's blog and collaboratively wrote group reflections using their group blog. A post-blogging survey was administered to elicit participants' perceptions on the use of blogs. The results of the surveys suggested that most of the students positively perceived the use of blogs for EFL learning. Only few students responded to the use of blogs negatively. The results also revealed that blogs have the potential for developing reading and writing skills. More detailed results and discussion are presented in the paper. Some pedagogical implications are also provided. For instance, teachers are suggested to post appropriate reading materials in the blog based on students' English abilities.

In 2012, Freeman and Brett examined a project in which blogs were implemented within an online graduate course in order to create opportunities for students to reflect on their academic, professional and personal interests, with the goal of establishing consistent blogging that exhibits the timely, frequent and interest-driven practices of blogging practices outside educational contexts. Students enrolled in an online graduate course maintained individual blogs in which they were prompted to write about their interests and experiences as graduate students. Through an analysis of the patterns of prompt use and blog content, as well as data from a post-course survey and an online discussion, it was explored how to support student engagement with blogging practice within an educational setting. Findings suggest that "frequency" of writing, "topic resonance" with the students own interests, and the "timeliness" of entries were key factors in scaffolding writing that aligns with blogging practice.

Marsden ; Piggot (2012). It was decided in this action research in the vocational trades area at UNITEC New Zealand to focus on students' writing on a new Level 3 course--the Certificate in Automotive and Mechanical Engineering (C.A.M.E.) in which all participants had netbooks or laptops for the first time. Blogging was selected because it introduces new possibilities in a field where one would not expect to see 
much written work by students. Using the "Problem Resolving Action Research" (PRAR) model (Piggot-Irvine, 2009), we approached the project in three stages. At the reconnaissance stage it was clear that writing skills did not enjoy a position of priority. The C.A.M.E. students' attitudes to writing in general were assessed, and to digital technology via the use of a questionnaire and a focus group. Then new approaches were implemented to teaching using digital technology in response to perceived needs. At the evaluation stage, further responses were collected via a questionnaire and a focus group on the students' attitudes to blogging and digital technology. Key findings included that the students were not discouraged by writing tasks, nor by digital technology, and that vocational tutors may need to play a more active role in embedding writing in courses.

Alterman, ; Larusson, (2013).This study shows the interaction between participation and the emergence of common knowledge. A case study of a single class provides the focal point of analysis. During the semester the students participated in a blogging activity. As a result of their participation, the students create and distribute knowledge. The online efforts of the students can be described as participation in both a discourse and knowledge community. At one level, blogging is an activity composed of writing, reading, and commenting, and at a second level, the students share their thoughts in their own voices. At a third level, over the course of the semester, the student posts and commentary form a commons of information that can be mined later in the semester for other kinds of learning activities. Knowledge creation, distribution, and accumulation are analyzed in terms of student participation at both the level of individual events and from the perspective of an ongoing community.

Using task-based activities to encourage students' interaction, Vurdien, (2013)shows how a blog as a computer-mediated tool engages a group of English as a Foreign Language learners at a language school in Spain in reflective and collaborative learning. Eleven students who were preparing for the Certificate in Advanced English (CAE) Cambridge examination were involved in a study that lasted for five months. All the participants created their personal blogs so that they could read each other's views, share ideas and comment on their peers' postings. The activities focused on the specific writing tasks (letter writing, report, proposal, and article) comprised in the aforementioned examination. The engagement in negotiation of meaning between peers 
led to better planning and the choice of the right register/style required in each task prior to writing and submitting their work. Collaborative skills were also fostered through students' regular interaction in the blogs. For meaningful learning to take place, pedagogical intervention could encourage students to take their peers' comments into account so that they can edit their own work with a view to enhancing their writing tasks and producing mistake-free texts.

\section{Commentary}

Through the review of literature, it is clear that there are differences between the current study and each one of the previous studies as the current study investigates the effect of blogs on developing some of the functional writing skills of second year secondary school students at Beni-Suef Governorate in Egypt

\section{Context of the Problem}

The researcher visited many schools during teaching practice . He had a look at tests to investigate the functional writing skills. He asked senior teachers and students through interviews about problems that students face in learning English. It was clear that students are weak in the functional writing skills. It was the idea of the current study.

To document the problem, a pilot study was conducted as follows:

\section{-To answer the first question of the present study which is:}

"What are the functional writing skills that are important to second year secondary school students?", the following steps were followed:

Description of the questionnaire: The purpose of the questionnaire is to know the functional writing skills which are important to second year secondary school students. The questionnaire involves 18 functional writing skills. In the questionnaire, scores ; (1) is given for disagree ,(2) is given for not sure and (3) is for agree. Senior teachers were free to select what they consider important according to their own points of view.

\section{Table(1) Reliability of the questionnaire related to senior teachers}

\begin{tabular}{|r|r|}
\hline $\begin{array}{c}\text { Cronbach's } \\
\text { Alpha }\end{array}$ & $\begin{array}{c}\text { N of } \\
\text { Items }\end{array}$ \\
\hline .817 & 18 \\
\hline
\end{tabular}

In table one, it is clear that reliability of the questionnaire is .817 
After determining reliability, the questionnaire was ready to be administered. The researcher chose senior teachers randomly from Nur Eddin Military Secondary School at Beni-Suef, Alnil Secondary School, Alsayeda Khadiga Secondary School for Girls at Beni-Suef, Alsayeda Aisha Secondary School for Girls at Beni-Suef, Secondary School for Girls, and Ihnasia Secondary School for Girls. The researcher made interviews with senior teacher in each school. Senior teacher were told what they had been able to do. Senior teachers were requested to select the items which are important to second year in secondary education. The atmosphere in which senior teachers answered the questions involved in the questionnaire was well. After senior teachers had finished selections, their responses were written down in a table. Then, statistical manipulations were carried out.

Table(2) The results of the questionnaire related to senior teachers

\begin{tabular}{|c|c|c|c|c|}
\hline & $\mathbf{N}$ & Sum & Mean & Std. Deviation \\
\hline VAR00001 & 27 & 47.00 & 1.7407 & .90267 \\
\hline VAR00002 & 27 & 69.00 & 2.5556 & .75107 \\
\hline VAR00003 & 27 & 63.00 & 2.3333 & .87706 \\
\hline VAR00004 & 27 & 38.00 & 1.4074 & .57239 \\
\hline VAR00005 & 27 & 52.00 & 1.9259 & .87380 \\
\hline VAR00006 & 27 & 46.00 & 1.7037 & .77533 \\
\hline VAR00007 & 27 & 53.00 & 1.9630 & .93978 \\
\hline VAR00008 & 27 & 64.00 & 2.3704 & .79169 \\
\hline VAR00009 & 27 & 79.00 & 2.9259 & 38490 \\
\hline VAR00010 & 27 & 51.00 & 1.8889 & .93370 \\
\hline VAR00011 & 27 & 52.00 & 1.9259 & .82862 \\
\hline VAR00012 & 27 & 66.00 & 2.4444 & .75107 \\
\hline VAR00013 & 27 & 77.00 & 2.8519 & .53376 \\
\hline VAR00014 & 27 & 38.00 & 1.4074 & .63605 \\
\hline VAR00015 & 27 & 77.00 & 2.8519 & .36201 \\
\hline VAR00016 & 27 & 46.00 & 1.7037 & .86890 \\
\hline VAR00017 & 27 & 72.00 & 2.6667 & .73380 \\
\hline VAR00018 & 27 & 57.00 & 2.1111 & .89156 \\
\hline Valid N & 27 & & & \\
\hline
\end{tabular}

According to the results in table 2 to diagnose the skills of the functional writing skills which are important to students in secondary education, it is obvious that the skills being selected by senior teachers are as follows:

2 (Punctuation). The mean is 2.5556 and the standard deviation is .75107

9 (Book Reviews). The mean is 2.9259and the standard deviation is .38490 
12 (Business Letter). The mean is 2.4444and the standard deviation is .75107

13 (Event Posters). The mean is 2.8519and the standard deviation is .53376

15 (Community Banners). The mean is 2.8519 and the standard deviation is . 36201

17 (Giving Pieces of Advice). The mean is 2.6667and the standard deviation is .73380

\section{As for suggestions, some senior teachers wrote the following:}

No.1 stated that there should be concentration on structure and vocabulary; besides, coherence of ideas

No.2 mentioned that mastering structure is important and there should be coherence of ideas

No.3 showed that there should be translations, mini-dialogues and correcting mistakes in grammar and novels

No.13 suggested that there should be due care to writing e-mail practically, not just on papers. In other words to use the Internet or the media lab.

No.22 stated that all mentioned points are sufficient.

No.23 wrote following: " As for writing skills which are taught in second year secondary education, teachers focus on writing letters, e-mail and composition(paragraphs).

After administering the questionnaire, the results showed that the skills which are important to secondary school students are : (Punctuation), (Book Reviews), (Business Letter), (Event Posters), (Community Banners), and (Giving Pieces of Advice).

Through the aforementioned information, it is obvious that students are in need of developing their functional writing skills through using one of the modern techniques through the Internet which is blogging.

\section{Statement of the Problem}

The problem of the present research lies in the fact that students are weak in some functional writing skills and the researcher attempts to make use of blogs and investigate their effect on developing some functional writing skills among 2 nd year secondary school students.

\section{4}




\section{Questions of the Study}

The questions are as the following:

(1) What are the functional writing skills that are important to second year secondary school students?

(2) What is the effect of blogs on developing each one of the functional writing skills which are important to second year secondary school students?

(3) What is the effect of blogs on developing the overall functional writing skills which are important to second year secondary school students in general?

\section{Aims of the Study}

This study aims to achieve the following:

-Investigating the effect of blogs on developing some functional writing skills.

- Using the Internet to develop the functional writing skills

- Developing the functional writing skills through activities

\section{Significance of the Study}

-This study might help to recognize the relationship between communication through the Internet and developing the functional writing skills

- Also, it might help in developing students' writing in secondary schools

- Further, it might give an idea about teaching and learning of the functional writing skills and how to make use of the Internet.

\section{Terms of the Study}

\section{Writing:}

Ibrahim (2003:24) defined writing as that skill through which the writer reflected his/ her thought, expressed his/her inner feelings. it was not merely putting down word by word to form a sentence or writing one sentence beside the other to form a paragraph. However it was the process through which the writers planned, organized their ideas, determined and used a paragraph outline, figured out meaning put it into language in a coherent identity. 
Nordquist (2014:1) defines writing as a system of graphic symbols that can be used to convey meaning.

The operational definition of Nordquist is adopted as it is consistent with the purpose of the current study.

Functional Writing means "Writing which communicates and interprets specialized information in a way that makes it useful for a reader. Reader-oriented writing which takes the complex and forbidding and makes it friendly, approachable, understandable and penetrable." Great Source Educational Group, Inc (2001:1).

Functional writing is a stylistic way of expressing specific information meant to mirror real-life scenarios such as how to overcome a difficult situation. Normally, it turns a complex subject into something that is more understandable to the readers. It involves making synopsis of a long story into something simpler. Ask.com.(2014:1)

The operational definition will be related to Great Source Educational Group, Inc (2001:1) as it is appropriate for the current study.

\section{Definition of a blog}

A blog is a Web site on which someone writes about personal opinions, activities, and experiences. Merriam-Webster Dictionary, (2014:1).

A Blog is an abbreviated word used for term "Weblog", This is a word used to describe different type of Websites and Portals which share information on specific topics or wider categories. It usually includes Features like Blog Posts, Videos, Comments, Links to other websites, Widgets, etc. Roshaan,(2013:2).

A blog (also called a weblog or web log) is a website consisting of entries (also called posts) appearing in reverse chronological order with the most recent entry appearing first (similar in format to a daily journal). Blogs typically include features such as comments and links to increase user interactivity. Blogs are created using specific publishing software. Gunelius, (2014:1).

The operational definition will be Gunelius's, (2014:1). as it is appropriate for the current study.

\section{Method of the Study:}

The method of the present study will be quasi-experimental 


\section{Instruments of the Study}

(1) Interviews with teachers, senior teachers at Ehnasia Secondary School for Girls and with supervisors at Beni-Suef Directorate

(2) A questionnaire to assess students' needs of some of the functional writing skills

(3) Pre/ post test to assess students' performance of some of the functional writing skills

Materials of the Study

-Student Book : Unit:11, P. 70 - Unit:12, P.75 - Unit:14, P.90

-Hairness, S.; Dallas,D.(2010:70- 90)

-Work Book: Unit:11, P. 70 - Unit: 12, P. 74 - Unit:14, P.86 - Unit:15, P.90

\section{-Hairness, S.; Dallas,D.(2010:70-90)}

-A program for developing the functional writing skills

\section{Delimitations of the Study}

\section{The study is delimited to}

- In the pre/test, there were 41 students enrolled in second year in BeniSuef Secondary School for Girls.

-Some functional writing skills including:

(Punctuation - Book Reviews - Business Letter - Event Posters Community Banners - Giving Pieces of Advice

\section{Participants of the study}

41 students were chosen randomly from Beni-Suef Secondary School for Girls. They were from the following classes: 2/4, 2/5, 2/7, 2/8, 2/9 during the second semester of the academic year 2014. After the post test, they were 32 students as some students were absent

\section{The Functional Writing Skills}

Functional writing is the practice of expressing specific information meant to mirror real-life scenarios such as how to make or do something, giving advice, inviting someone to something or telling what happened in a specific situation. "Functional writing often turns a complex subject into something that is more understandable to the reader. 
Fortney,(2013:1-3) stated that teachers can help students master this type of writing by assigning various functional writing activities as the following:

* "How To" is a familiar form of functional writing. Students should be offered a long list of scenarios in which they must explain, in detail, how tasks are completed. Using the example "How to make toast," students should paint a clear picture with words as to how toast is made, from taking the bread out of the bag to buttering the toasted top, ensuring that someone who has never made toast before could complete the task. "How to wash a car," "How to be a good friend" and "How to draw an elephant" are other examples.

* "Book Review": Students should be asked to write a review of a book that has recently been read. The book review should contain a synopsis that gives the reader a general idea of what was covered in the book. Also within the book review, the student should offer her personal thoughts and state whether she would recommend the book to a friend.

"Letters": Both formal and informal letters can be used to practice functional writing. Formal letters are typically used for official business, like applying for a job, leaving a job, asking for permission or contacting companies or school institutions. Informal letters are used when communicating with a friend or relative for the purpose of apologizing, inviting, explaining, thanking or expressing feelings. Teach the class the characteristics of each letter format and ask them to write examples of both.

* "Notices": A notice is used to announce something specific, such as an upcoming event, a warning or advice, and is typically placed in a location that is not only relevant to the information but will also be seen by the intended parties. Have the students create notices that can be hung around the classroom or school. Notices can be short phrases such as "Do not disturb," Keep the light on," No food or drink" or "Testing in progress." In some cases, notices may start with a short phrase but then include additional information that explains the warning or advice in more detail. Events announced with notices should answer the who, what, when, where and why questions.

.(The Educational Company of Ireland, (2014:1-11) stated that there are some other functional writing skills as the following: 
Letters, reports, speeches, reviews, a curriculum vitae, advertisement or Brochure, describing photographs/pictures and blurbs

\section{The six key requirements of Functional Writing are :}

1. use language with an appropriate register. This means that you must write in an appropriate tone and with appropriate vocabulary for the specific task and audience.

2. have a clear sense of who you are writing for.

3 . write with a strong sense of purpose.

4. give your writing a shape or layout that conforms to accepted standards (e.g .for a letter, the placing of the address in the top right-hand corner).

5. punctuate accurately and observe the rules of grammar.

6. keep your content relevant to the question.

According to Minguel Bengoa ELT(2013:1-2), writing sub skills are classified as the following:

1. Manipulating the script of the language: handwriting, spelling and punctuation.

2. Expressing grammatical [syntactic and morphological] relationships at the sentence level

3. Expressing relationships between parts of a written text through cohesive devices [especially through grammatical devices such as nounpronoun reference].

4. Using markers in written discourse, in particular:

-introducing an idea

-developing an idea

-transition to another idea

-concluding an idea

-emphasising a point [and indicating main or important information]

-explaining or clarifying a point already made

-anticipating an objection or contrary view

5. Expressing the communicative function of written sentences:

\section{9}

Journal of Arabic Studies in Education \& Psychology(ASEP) 
-using explicit markers

- without using explicit markers

6. Expressing information or knowledge in writing:

-Explicitly

- implicitly

7. Expressing conceptual meaning

8. Planning and organising written information in expository language

- Narrative

- straight description of phenomena or ideas

-descriptions of process or change of state

- argument

Teachers need to do less lecturing to students about what they should be doing in their writing and more actively involve their students in learning. "Criteria guided revision activities that use peer response groups work best just before students are given their final assignments. Teachers who use these types of activities will see the quality of their students' writing begin to improve." Johannessen, (1995:1).

\section{Procedures of the Study}

\section{The Program and Pre/Post Test Design}

The program involves the skills selected by senior teachers after administering the questionnaire to investigate the most important skills that are used in secondary school students. The skills selected are (Punctuation), (Book Reviews), (Business Letter), (Event Posters),

(Community Banners), and (Giving Pieces of Advice). The program consists of six units. Each unit is divided into two parts. The researcher prepared a student's Book and a Teacher's Guide. They were submitted to Jurors. The researcher took permission from security affairs of BeniSuef Administration to carry out the program, then he went to Beni-Suef Secondary School for Girls. The researcher met the School Principal, teachers and senior teachers and they helped him.

Test Validity :A pre/post test was prepared and it was submitted to Jurors to achieve validity to assess what the test is put for. 


\section{Test Reliability:}

Table (3) Reliability o
\begin{tabular}{|l|l|}
\hline skills & $\begin{array}{l}\text { Alpha } \\
\text { reliability }\end{array}$ \\
\hline Skill 1 & .87 \\
\hline Skill 2 & .84 \\
\hline Skill 3 & .85 \\
\hline Skill 4 & .83 \\
\hline Skill 5 & .85 \\
\hline Skill 6 & .86 \\
\hline
\end{tabular}

Reliability is ranged from .83 to .87 . The pre/test was administered. Inter-raters helped the researcher after administering the test to be away from bias.

The student's Book was given to students. The senior teacher was given the Teacher's Guide as he was helpful to the researcher in classes.

Students were asked to send e-mails answering the questions mentioned at the end of each unit of the program. With the help of senior teachers, students were encouraged to send e-mails to the researcher.

The girls who attended the pre/test were 41.After administering the pre/test, the researcher gave the student's Book to the girls, who were chosen from different classes. The classes were: $2 / 4,2 / 5,2 / 7,2 / 8$, and $2 / 9$. The researcher visited the school three times a week. He met students and told them about the program and how to send the answers to the exercises of the Student's Book through the Internet. The researcher gave the participants his e-mail which is Mukhaeae@yahoo.com .The researcher was helped by a senior teacher at Beni-Suef Secondary School for Girls. The senior teachers exerted great efforts and they were helpful to the researcher while applying the program to the school girls before administering the post test.

\section{How to teach the Functional Writing Skills}

It is imperative for teachers to lay emphasis on the functional writing skills to enable learners compete for job opportunities favorably and also survive on job by being able to write correspondences in the right way.

\section{1}


Swaga,(2013:1) pointed out that teachers should guide learners on the format, content, language and purpose of job application letters. This can be done by getting job advertisements from newspapers and helping learners do practice on writing applications. They should guide learners on how to write personal profiles. There are many prestigious universities overseas that offer scholarships to students who excel in academics, leadership skills and community service but some of the applicants fail to write good personal profiles because they do not have adequate information about the format, content and language that should be used. We should be able to teach them how to brand themselves in order to secure such opportunities. Also, they should help learners to do practice in writing other types of formal letters like requisitions, claims and apologies among others. Such letters are commonly written in the field of work.

\section{Blogging and Cultural Learning}

"Blogs allow for a better incorporation of culture in the language classroom as they "expand the walls of the classroom" (Richardson ,2006:28)

This factor alone allows for the integration of culture into every aspect of language learning. Students are able to connect to things and places from around the world, by linking to videos, websites, and blogs from native speakers. "Blogging in an academic classroom setting

enables knowledge sharing through connecting learners to contexts beyond the classroom." (Sun \& Chang, 2012:43).

According to Blacksburg, ((2014: 2-3) the teacher should consider the following points:

* "Determine the requirements for a blogging site that students can use.

* Use a free, Internet-based site. These sites allow students to connect from any place there is an Internet connection,

* Use an Intranet-based site. Intranet sites can be set up within your school or district network, so they are usually accessible only from school computers or via school logins.

* Discuss the features that are available in the blogging site that you have chosen for students. 
* Students should know how to accomplish basic tasks such as making text bold or italics and adding a hyperlink.

* Choose writing activities that fit your goal for the blogs.

* Once a post is published, show students how to revise a post if necessary.

* Emphasize the importance of providing useful suggestions and supportive feedback.

* Add details on your district's acceptable use policy as appropriate.

* Begin the commenting process by asking students to respond to a certain number of blogs each week.

\section{Significant Characteristics of Blogs}

A great blog transfers knowledge, ideas and experiences.

There are some guidelines for creating cogent, intelligent, and powerful content for a blog. Collins, (2012:1-2).

1) 'Make it Pertinent

Without relevant content it is wasted breath. A person should know audience and gauge what will not only be appropriate, but pertinent.

2) Include Useful Information

People appreciate information they can do something with, and will return to a blog

3) Make it Engaging

A blog post must be well written. It needs to be personal, interesting, and interactive.

4) Spark Discussion

It is extremely important to generate as much conversation and discussion as possible in a blog.

5) Keep it Readable

Bullets, lists, graphs and images are a great way to make sure that content is easy to read. Always preview work before being published.

6) Appropriate Length 
A blog post should be as long as it needs to be to succinctly and clearly explain ideas, concepts or thoughts.

"The significance of the blog is that it is dynamic. It can be updated. It allows the visitor to communicate .

The other significant characteristics of today's blogs are:

- a blog has some form of navigation, usually menus

- a blog's layout contains a header, footer and content. Usually there is at least one sidebar running beside the content.

- categories of posts

- that readers can access the archives, previous posts

- that a post can contain text and images, (and often video and other media)

- that posts can contain links to other posts.

- should contain a contact page, form and an about page

In today's world a blog may contain many other elements, such as a display of recent posts, a plug in that automatically sends a new post details to Twitter or Facebook, image galleries and the ability to turn the post into an easy to print document." Byrd, (2014:1).

\section{A Blog Is Really about Communication}

Byrd (2014:2) added that a blog, with a lot of work, is a very effective way of reaching out and communicate with a sizeable audience . A person can read personal thoughts; inform people; tell them about campaign; attract potential customers to services or business; or sell something.

In all these cases you are communicating and in most cases you are trying to get the visitor to take some form of action, even if it is only to click a link to read another post on your site.

The researcher sent replies to students' e-mails urging them to send more . Through meetings in school, the researcher corrected the students' mistakes and errors. The points that were vague, the researcher pointed them out as the following:

\section{Some Students'Responses through the Internet}

esoo mohamed

\section{4}


To Mukhaeae@yahoo.com

Mar 25 at 3:04 PM

\section{Punctuation}

1:c) $3:$ c) $5: d)$

"Part two " 2:a) 4: b) 6:c) 8: c) 10:a)

soha soha unit 1part one: 1_(c) 2_(a) 3_(c)

part two:2_(c) 4_(b) 6_(c) 8_(c) 10_(b)

Today at 11:22 AM

To soha soha

Today at 10:28 PM

Thanks for sending your answers. I hope that you will send me the answers of other questions. The best of luck.

Dr. Mukhtar

On Tuesday, April 1, 2014 11:33 AM,

Mena Mostafa $<$ menamostafa1@yahoo.com> wrote:

unit 1 part one 1_(b) 2_(a) 3_(c)

part2 2_(c) 4_(b) 6_(c) 8_(c) 10_(b)

To Mena Mostafa

Today at 10:30 PM

Thanks, very much. I hope that you will send me other answers of other questions. My best wishes.

Dr. Mukhtar

omnia ehab

To Mukhaeae@yahoo.com

Apr 3 at 1:52 PM

unit 1 part 1 1...c $3 \ldots$ d $5 \ldots$. d

part $2 \quad 2 \ldots$. a 4 ....a 6 ...c 8 ...c $10 \ldots$ d

To omnia ehab 
Today at 7:59 PM

Our obedient student,

Thanks so much. I am happy after receiving your messages. Please, ask your colleagues to send more. I shall visit your school tomorrow to discuss our English program which deals with the functional writing skills. My Best wishes

\section{Dr. Mukhtar}

\section{Discussion of Mistakes and Errors:}

In the old Secondary School for Girls at Beni-Suef, students were told the model answers in order to know their errors. Correcting mistakes and errors is considered to be as feedback to improve their achievement afterwards.

The model answers are as the following:
Unit One Part One
(1) $\mathrm{d}$
(3) a
(5)a
Part Two
(2) $a$
(4) b
(6) c
(8) c
(10) a

esoo mohamed

To Mukhaeae@yahoo.com

Mar 25 at 3:04 PM

\section{Book review}

\section{"Hamlet"}

Once upon a time there was a king called Hamlet who was killed with the poisonous by his brother. After his death, his brother married his wife, but the king's son, who was called hamlet too, wasn't satisfied to his mother or his uncle. One day, he was waking when he saw his father's ghost and it told him that his uncle had killed him with the poisonous and it asked him to take revenge on his uncle. When he decided to kill his uncle, he killed his advisor by mistake, but this advisor's son wanted to kill Hamlet, but he could hurt him by a poisonous sward. Hamlet could kill him. Then he killed his uncle after his mother's death with the poisonous which Hamlet wanted to give him 'but Hamlet refused although his mother drank it by mistake. Then, Hamlet died, too.

\section{Discussion of Mistakes and Errors:}

\section{6}


The student was asked to use "with poison" instead of "with the poisonous" , "poison" instead of "poisonous" and "the poison which" instead of "the poisonous which"

esoo mohamed

To Mukhaeae@yahoo.com

Mar 25 at 3:04 PM

"Part two"

My Dream.

My dreams are unlimited. I hope I will be one day a good doctor and a useful woman for my society. I wanted to be a doctor to help poor patients who don't have money to be treated I hope I make my doctorate abroad and live there with my family. I also hope I complete rememorizing the Holly Quran and to teach it.

\section{Discussion of Mistakes and Errors:}

The student was asked to omit "to be treated". She was also asked to use "do" instead of "make" and "my Ph.D" instead of "my doctorate". The student was also asked to write "that I shall complete" instead of "I complete" and "teach" instead of "to teach".

omnia ehab

To Mukhaeae@yahoo.com

Apr 3 at 6:22 PM

\section{Unit 2 Part 1}

I read a book called "The princess Cindrella". I enjoyed reading this book. There was a girl called Cindrella. Her mother died and her father married a woman. She was an evil woman .She had 2 girls. They were like her (the same evil). She made Cindrella made evy thing.Her daughters did not like Cindrella because she was beautiful. One day the prince sent invitations to every girl in the kingdom to come to a party so that he could choose agirl to marry her.Cindrella,s father,s wife prevented her from going. She cried but suddenly an enchantress woman appeard and gave her asmart dress. She went to the party.The Prince admired her and eventually they got married.We should learn that the evil is a bad thing.

\section{Discussion of Mistakes and Errors:}

\section{7}


The student was asked to use "Every" instead of "Evy","a girl" instead of "agirl", "Cindrella's father's wife" instead of "Cindrella,s father,s wife" and "a smart" instead of "asmart"

omnia ehab

To Mukhaeae@yahoo.com

Apr 3 at 2:01 PM

\section{Unit 2 Part2}

My dream is to be a doctor.I like this job too much .You can help any one in different conditions. I was walking once. I saw a boy was cring and suddenly fell down to the ground .At this moment I amagined if I was a doctor I would help him .I ask Allah to help me to score this goal. I am sure Allah will help me .I want to help poor people who do not have enough money to go to the doctor. Finally: Live with love and obey Allah to be happy in your life.

\section{Discussion of Mistakes and Errors:}

The student was encouraged and asked to use "achieve my hope" instead of "score this goal". She can also can use "crying' instead of 'was cring" and 'imagined' instead of 'amagined'

omnia ehab

Today at 2:04 PM

$\mathrm{Me}$

To omnia ehab

Today at 11:55 PM

To our student,

Thanks very much as you obeyed your teachers. I hope that you will be a doctor, Omnia. Work hard, obey your parents,listen to your teachers' pieces of advice and be helpful to your friends. We pray Allah to help you. My best wishes

\section{Dr. Mukhtar}

esoo mohamed

To Mukhaeae@yahoo.com

Mar 25 at 3:04 PM

\section{8}


Unit Three. Part One

Salah Salem Street,

Beni suef.

20-3-2014.

Dear suha,

How are you?

I am very pleased to write this letter to you and I am happy to tell you that we will meet soon as I miss you very much. Fortunately, my mother had agreed and I will come and visit you to stay a week with you during the summer holiday. I can't wait a lot. I want to see you and spend a good time with you.

Best wishes.

Sincerely yours,

Huda.

\section{Discussion of Mistakes and Errors:}

The student was able to write successfully the letter as it is a reply to an invitation. This means that the student's performance is well.

esoo mohamed

To Mukhaeae@yahoo.com

Mar 25 at 3:04 PM

\section{"Part two"}

Aljazeera,

Tharwat street,

Beni suef.

Ataba,

Tele no.0822318563,

Cairo.

Facsimile: 0822328563.

Dear the manger of the computer company,

Hi am very sorry to tell you that I am very sad from delaying the computer delivery. I am complaining of delaying. The computer delivery within a week of the date of the order, but it delayed for many days, I asked you to deliver it quickly, please.

\section{9}


Yours,

Mr. Mahmoud.

\section{Discussion of Mistakes and Errors:}

The student is asked to write the sender and address on the right side of the letter and on the left, the student is asked to write the name and address to whom the letter will be sent. The student is asked to write "I am sorry" instead of "Hi am very sorry", "sad at" instead of " sad from" and "should be within" instead of "within"

omnia ehab

To Mukhaeae@yahoo.com

Apr 3 at 7:49 AM

\section{Unit 3 Part 1}

Salah Salem Street

Beni-Suef

$16 / 3 / 2015$

Dear

It gives me great pleasure to write to you . How are things? That's agood idea .I will come with my sister. I hope we will enjoy .

\section{Yours}

Huda

\section{Discussion of Mistakes and Errors:}

The student was asked to write "Dear Suha," instead of "Dear", "a good idea" instead of "agood idea" and "will enjoy our time" instead of "will enjoy."

omnia ehab

To Mukhaeae@yahoo.com

Apr 3 at 8:02 AM

Unit 3

Part 2

Mr Mahmoud

\section{0}

Journal of Arabic Studies in Education \& Psychology(ASEP) 
Algazeera

Beni-Suef

Tharwat Street

Tele: 0822318563

Ataba

Facs:0822328573

Cairo

8 March 2014

I am sorry to say that the computers delivary delayed. It should came in $10 / 3$ but it came in $15 / 3$.

Sincerely yours

Mahmoud

\section{Discussion of Mistakes and Errors:}

The researcher told students about their errors in writing prepositions . The student was asked to write on instead of in. The student was also asked to write "should come" instead of "should came" and "delivery" instead of "delivary."

esoo mohamed

To Mukhaeae@yahoo.com

Mar 25

\section{"Posters"}

The countryside

The country cide is a beautiful place where there is pure air and water. You can enjoy your time there without the noise of cars, rush hour and the crowded streets of over population. Air is clean without pollution. The people there are neighbors as they live together, share their happiness and sorrows together. They spend their time farming and enjoy their work, but nowdays, many of them had to move to the town to find much work. Their houses are so close. They keep their customs and traditions. The green plants make them relaxe. They keep chikens and ducks and they can also catch fish from rivers. They don't have any technology, but their ideas are so modern.

\section{Discussion of Mistakes and Errors:}

\section{1}

Journal of Arabic Studies in Education \& Psychology(ASEP) 


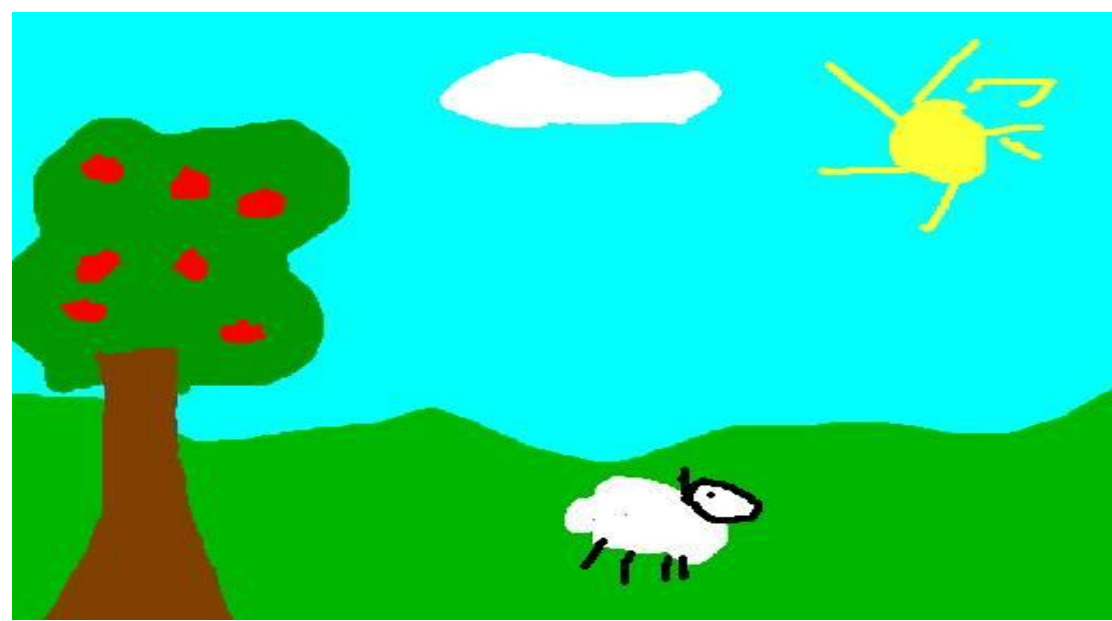

The student was asked to show a design, but not to write a paragraph. Anyhow, the student is asked to correct his errors as the following:

The student is asked to write "The countryside" instead of "The country cide", nowadays instead of "nowdays", "narrow" instead of "close", "relax" instead of "relaxe" and "chickens" instead of "chikens"

Unit 4 Part 1 [No Subject] omnia ehab

To Mukhaeae@yahoo.com

Apr 5 at 8:09 AM

\section{A Poster Describing the Countryside}

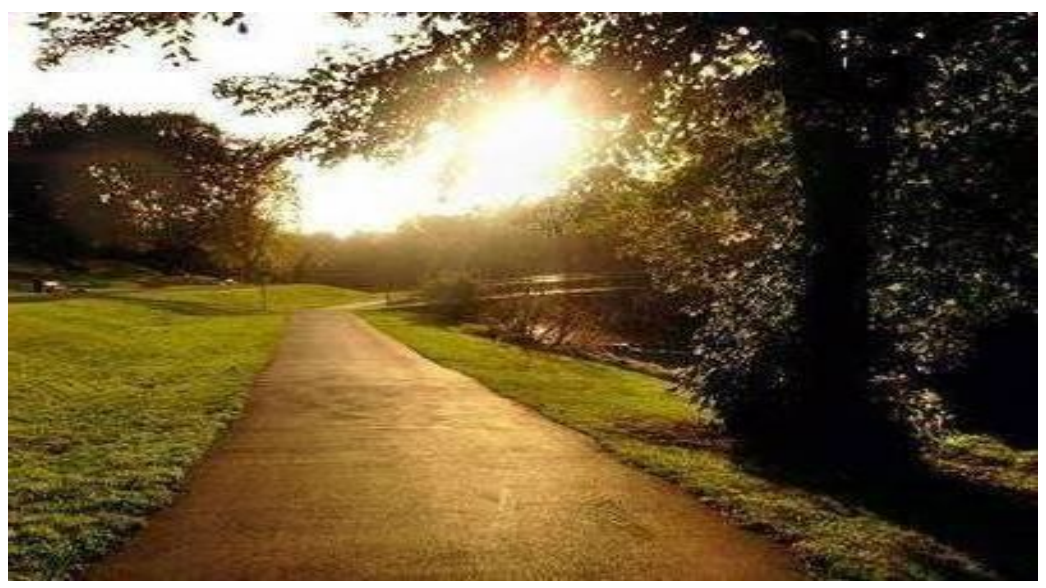

Unit 4 Part 2 [No Subject] 
omnia ehab

To Mukhaeae@yahoo.com

Apr 5 at 8:11 AM

A Poster about the Seasons of the Year
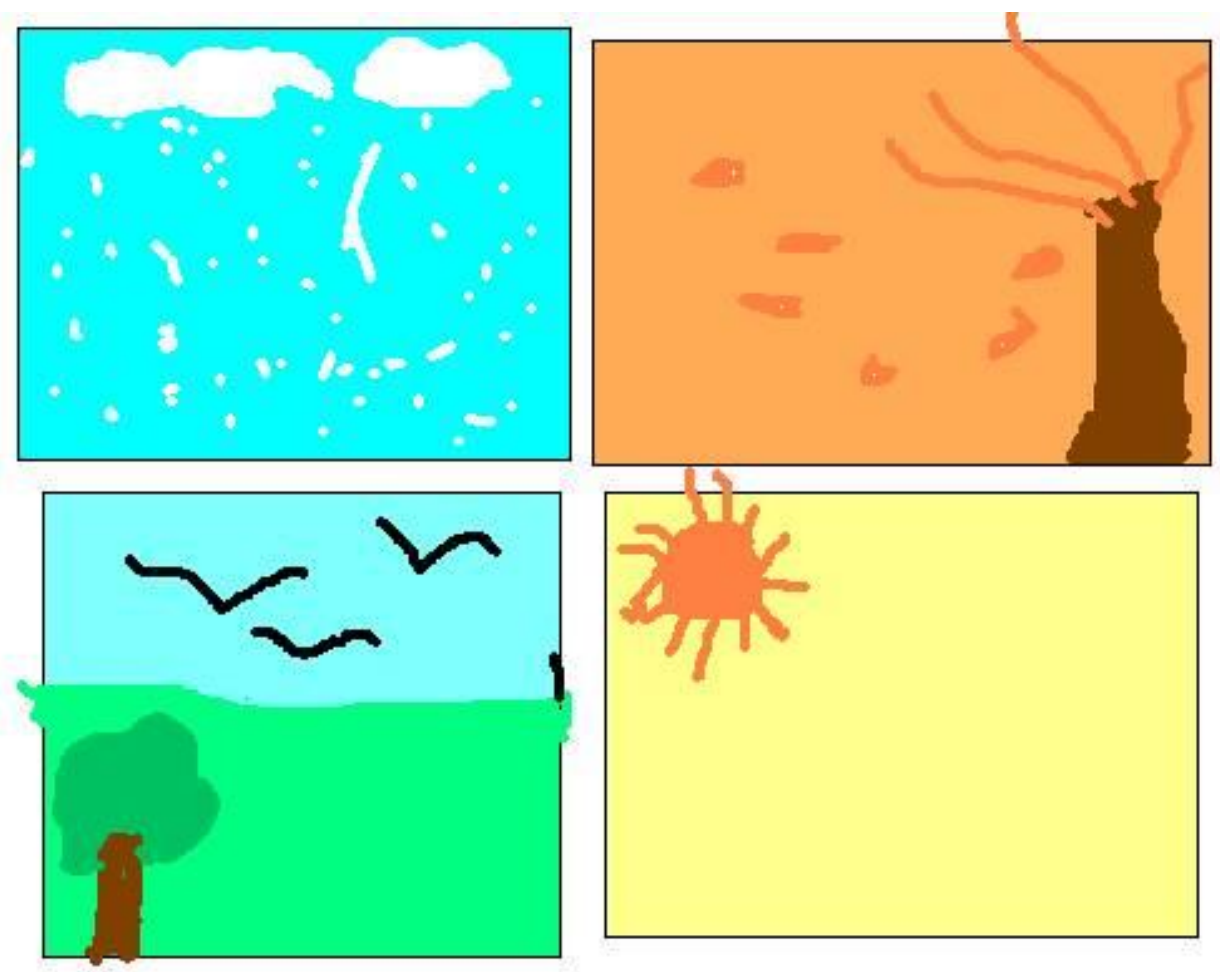

Unit 5 Part 1 omnia ehab

To Mukhaeae@yahoo.com

Apr 5 at 8:12 AM

A Community Banner, Describing " Mother's Day "

Unit 5 Part 2 [No Subject]

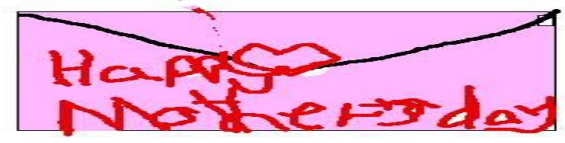

\section{3}

Journal of Arabic Studies in Education \& Psychology(ASEP) 
omnia ehab

To Mukhaeae@yahoo.com

Apr 5 at 8:15 AM

\section{A community Banner, describing " Our Summer Camp "}

\section{Discussion of Mistakes and Errors:}

Students were praised as their activities were splendid. Posters and banners were discussed .Students were told to consider punctuation as Mother Day in Unit Five, Part One

esoo mohamed

To Mukhaeae@yahoo.com

Mar 25 at 3:04 PM

"Part One"

"Giving pieces of advices"

1- I come to school on time and never come late.

2- I stay in class and I don't leave my school lessons.

3- I listen well to my teacher.

4- I am stay in silence in the class.

5- I always answer to the questions which the teacher asks.

6- After the lesson I sit with my friends and talk together.

\section{Discussion of Mistakes and Errors:}

The student was asked to write " I stay " instead of "I am stay" and " the questions" instead of "to the questions"

"Part two"

1 -you should rememorize new wards and write it down.

2-never delay today's work until tomorrow.

3-take more exercises.

4-listen to the teacher well.

5 - study between lines.

6-remember why you study English.

7-pinpoint your weakness.

8-have fun with this subject.

9-never give up.

10-if you don't succeed try, try and try again.

To esoo mohamed

\section{4}


Mar 25 at 7:18 PM

Our brilliant student,Thanks so much. Please, ask your colleagues to send me other messages involving answers of four or five questions. I shall visit your school on Sundays, Tuesdays and Thursdays. I am looking forward to your reply. Best regards

Dr. Mukhtar

\section{Discussion of Mistakes and Errors:}

The student was asked to start any sentence in English with a capital letter. He was asked to write "words instead of "wards', "them" instead of "it", "Do" instead of "take", "your" instead pf "this"

omnia ehab

To Mukhaeae@yahoo.com

Today at 8:21 AM

1.should

Unit 6 part 1

2.shouldnot

3.should ,should

4. shouldnot should

5. should shouldnot

6. should

7. should shouldnot shouldnot should should shouldnot

\section{Discussion of Mistakes and Errors:}

The student gave the model answers of questions, but writing the apostrophe was not correct. She was told to write the abbreviation as follows: "shouldn't" in speaking, but "should not" in writing omnia ehab

To Mukhaeae@yahoo.com

Today at 8:26 AM

Unit 6 part 2

-If I were you, I wouldnot watch TV or go to the club .

-You should do your best to pass the test.

-Listen to your self.

-Study hard and rvise well .

\section{Discussion of Mistakes and Errors:}

The student was asked to write "would not" instead of "wouldnot" and "teacher" instead of "self.". She was also asked to write "revise" instead of "rvise" 


\section{Administering the post test and Findings of the Study}

Some students did not attend the post test .The researcher omitted their answer sheets in the pre-test .Numbers of students who did not attend were the following numbers: $1,2,3,4,5,10,30,31$ and $40.1,2,3,4,5$ and 10 were from 2/4.Numbers 30 and 31 were from $2 / 8$ and number 40 was from $2 / 7$ The students' numbers were rearranged again. The students became 32 after they had been 41 . Those who did not attend might have difficult circumstances or because they might have been at the end of the academic year and might have been preparing for the final test at school.

To answer the second question which is "What is the effect of blogs on developing each one of the functional writing skills which are important to second year secondary school students?, the findings are in the following table:

Table (4) Mean scores and standard deviation of pre-post test on the functional writing skills

\begin{tabular}{|ll|l|l|l|l|}
\hline & & Mean & $\mathrm{N}$ & Std. Deviation & Std. Error Mean \\
\hline Skill 1 & post & 8.2969 & 32 & 1.07658 & .19031 \\
& pre & 5.9688 & 32 & 1.36155 & .24069 \\
Skill 2 & post & 10.4688 & 32 & 1.39085 & .24587 \\
& pre & 9.0625 & 32 & 2.36831 & .41866 \\
Skill 3 & post & 10.3125 & 32 & .85901 & .15185 \\
& pre & 7.8750 & 32 & 1.64120 & .29013 \\
Skill 4 & post & 18.4063 & 32 & 1.54208 & .27260 \\
& pre & 10.5000 & 32 & 2.70006 & .47731 \\
Skill 5 & post & 11.0313 & 32 & 1.06208 & .18775 \\
& pre & 6.7500 & 32 & 1.72271 & .30454 \\
Skill 6 & post & 15.7500 & 32 & 1.16398 & .20576 \\
& pre & 9.1563 & 32 & 2.47711 & .43790 \\
& & & & \\
\hline
\end{tabular}

It is shown that the mean in pre-test is 5.9688 in skill 1 , whereas, the mean in the post test is 8.2969. Dealing with standard deviation, in the pre-test, it is 1.36155, while in the post test it is 1.07658 . In skill 2 , the mean in the pre-test is 9.0625 , but in the post test, it is 10.4688 . Considering standard deviation, in the pre-test, it is 2.36831 , while in the post test, it is 1.39085. The mean in pre-test is 7.8750 in skill 3, whereas, the mean in the post test is 10.3125 . Dealing with standard deviation, in the pre-test, it is 1.64120, while in the post test, it is .85901 . In skill 4 , the mean in the pre-test is 10.5000 , but in the post test , it is 18.4063. Considering standard deviation, in the pre-test, it is 2.70006.while in the post test, it is 1.54208 . The mean in the pre-test in skill 5 is 6.7500 , but it is 11.0313 in the post test. Regarding, standard 
deviation, it is 1.72271 and it is 1.06208 in the post test . In skill 6 , the mean in the pre-test is 9.1563, but in the post test, it is 15.7500 . Considering standard deviation, in the pre-test, it is 2.47711, while in the post test, it is 1.16398 .

It is obvious that means of the post test are more than those of the pre teat. These results show that students in Beni-Suef Secondary School made use of the function writing skills' program.

To answer the third question which is: "What is the effect of blogs on developing the overall functional writing skills which are important to second year secondary school students?", the following results are shown:

Table(5) The results of $T$ Test to measure the differences between the pre-test and the post-test of the experimental group

\begin{tabular}{|c|c|c|c|c|c|c|}
\hline Skills & $\begin{array}{l}\text { Mean } \\
\text { Differenc } \\
\text { es }\end{array}$ & $\begin{array}{l}\text { Std. } \\
\text { Deviation } \\
\text { Differences }\end{array}$ & $\begin{array}{l}\text { Std. Error } \\
\text { Mean } \\
\text { Differences } \\
\end{array}$ & $\mathbf{T}$ & df & Sig. (2-tailed) \\
\hline Skill 1 & 2.32813 & 1.47347 & .26048 & 8.938 & 31 & .01 \\
\hline Skill 2 & 1.40625 & 2.57606 & .45539 & 3.088 & 31 & .01 \\
\hline Skill 3 & 2.43750 & 1.70270 & .30100 & 8.098 & 31 & .01 \\
\hline Skill 4 & 7.90625 & 3.23648 & .57213 & 13.819 & 31 & .01 \\
\hline Skill 5 & 4.28125 & 2.01981 & .35706 & 11.990 & 31 & .01 \\
\hline Skill 6 & 6.59375 & 2.67436 & .47277 & 13.947 & 31 & .01 \\
\hline Total & 25.17188 & 7.42447 & 1.31247 & 19.179 & 31 & .01 \\
\hline
\end{tabular}

It is shown that the total of the mean differences is 25.17188 , standard deviation is 7.42447 .

Std. Error Mean is .55438 and the value of T is 19.179.

\section{Discussion and Interpretations of the Study.}

In the pre/test, the lowest score was 27, while the highest score was 60 . In the post/test, the lowest score was 65 and the highest score was 80.5 This is because students benefited from the program. They told the researcher that they studied the program well and made use of it. The researcher answered their questions related to the program during his visits to school. It is clear in standard deviations that the values are nearer to the highest values. It means that the effect of the program is positive. Students' scores have become higher in the post test.

Considering $\mathrm{T}$ test in table (5), it has been shown that students were improved in all skills of the functional writing skills I,2,3,4,5and 6 . 
There were statistically significant differences at the level $(0.01)$ in favour of the post test .

The current study dealt with blogs and their effect on some functional writing; it is different from Mourad's(2009) because Mourad dealt with the effectiveness of program based on the self-regulated strategy development of writing skills in writing-disabled secondary school students. Only few students responded to the use of blogs negatively as the study of $\mathrm{Wu}$, and $\mathrm{Wu}(2011)$. Using task-based activities to encourage students' interaction, is to be taken into account as the study of Vurdien, (2013). This study came up with findings that may help students in their future whether in secondary schools or the universities.

\section{Recommendations of the Research}

As a result of the present research, it is recommended to consider the following:

- Helping students know more about their environment develops their experiences and skills involved in writing.

- There should be training courses involving the functional writing skills

- Encouraging students to share, take care and tell about their experiences is important in teaching the functional writing skills

- The functional writing skills should be based on theory and practice.

- Motivation, mutual respect, and cheerful atmosphere should exist in teaching writing.

- Sharing in publications, gives writers a sense of ownership and develops the functional writing skills.

- Providing students with choice over their writing activities, autonomy, appropriate challenges and process versus product evaluation could encourage students to value their efforts and achieve tangible progress in writing.

- Action Plan is successful in increasing writing fluency.

- -"Learning by design" enables teachers to offer high quality learning experiences to their students.

- The instructor-student interaction is positive, as it enhances participants' learning motivation and compositional ability.

- Helping teachers understand the potential benefits of blogging and journaling increases the content and voice writing skills of their students.

- Students can complete blogging tasks in class rather than after class.

- Encouraging students to take their peers' comments into account can help students edit their own work with a view to enhancing their writing tasks and producing mistake-free texts.

\section{8}




\section{Suggestions for Further Studies}

According to the results of the study, the following studies are suggested :

- The Effect of Blogs on Developing the Reading Skills

- The Effect of Using the Internet on Developing Pronunciation SubSkills

- The Effect of Using Group Work through the Internet on Developing Primary School Pupils Handwriting

- The Effectiveness of a Writing Activities- Based Program in Developing Some Speaking Skills of Students in Preparatory Stage

- The Effect of Using Blogs on Developing Listening Comprehension Skills

- The Effect of Home Assignment and Blogs on Developing Students' Handwriting in Preparatory Stage

\section{References}

- Alterman, R.; Larusson, J. A. (2013). "Participation and Common Knowledge in a Case Study of Student Blogging", International Journal of Computer-Supported Collaborative Learning, V.8, N. 2 PP. 149-187

- Anderson, D. B.(2010)."The Effect of Blogging and Electronic Journaling on Writing Skills Development in High School Freshmen", in ProQuest LLC, Ph.D. Dissertation, Walden University.

- Anderson, D. et al. (2003). Improving Writing Skills in the Elementary Classroom. M. A. Project, Saint Xavier University and Skylight Professional Development Field-Based Master's Program.

- Ask.com.(2014) "Definition of Functional Writing", Retrieved from:http://www.ask.com/question/definition-of-functional-writing, on $15 / 2 / 2014$

- Benischek, D. et al. (2001). Improving Writing Skills in the Primary Grades. M.A. Project. Southwest Regional Laboratory for Educational Research and Development, Los Alamitos, CA.

- Bizymoms(1997)"Internet Communication", Retrieved from : http:// www.bizymoms.com/computers-and-technology/internetcommunication.html, on 3/3/ 2014 
- Blacksburg, V.(2014)."Teaching With Blogs", Retrieved from: http://www.readwritethink.org/professional-development/strategyguides/teaching-with-blogs-30108.html, on 10/3/2014

- Byrd, K. (2014). "Blog Basics. Characteristics of a Blog", Retrieved from: http://blogbasics.com/characteristics-of-a-blog/, on 7/3/2014

- Cary, T.(2013)."Types of Internet Communication", Retrieved from: http://www.ehow.com/about 5380840 typesinternetcommunication.h $\underline{\mathrm{tml}}$, on $5 / 3 / 2014$

- Catch my party.(2011)"Amazing Mother's Day Parties and Free Printables!", Retrieved from:http://catchmyparty.com/blog/category/ printables-free-mothers-day

- Collins, C. (2012). "Characteristics of a Great Blog Post", Retrieved from: http://pageonepower.com/2012/05/6-characteristics-great-blogpost $/$, on $2 / 3 / 2014$

- Cox, T.L.(2012). Promoting Blogging to Improve Interpersonal and Presentational Writing Skills While Increasing Cultural Competency in an English Language Learning Setting. M.A., University of Arkansas at Little Rock

- English Exercises,(2014:1). "Sickness Exercises", Retrieved from: http://www.englishexercises.org/makeagame/viewgame.asp?id=1734

- Fessakis, G., et al (2008)."Supporting "Learning by Design" Activities Using Group Blogs", in Educational Technology \& Society, V.11 N. 4 PP. 199-212

- Fortney, D.(2013) "Functional Writing Activities", Retrieved from: http://www.ehow.com/info_8144477_activities-functionalwriting.html, on 2/3/2014

- Freeman, Wendy; Brett, Clare(2012)."Prompting Authentic Blogging Practice in an Online Graduate Course", in Computers \& Education, V.59 N.3 PP.1032-1041

- Gebhard, M.; Shin, D.-S.; Seger, W. (2011). "Blogging and Emergent L2 Literacy Development in an Urban Elementary School: A Functional Perspective", in CALICO Journal, V. 28 N.2 PP.278-307

- Great Source Educational Group, Inc (2001). "Definition of functional Writing", Retrieved from: http://team.boe.ttct.edu. tw/ceag/upload/2\%20functional_writing_rubric.pdf, on 4/3/2014

\section{0}


- Google.com.(2014)."Banners' Activities", Retrieved from: https://www.google.com.eg/search?q=Banners\%27+Activities\&rlz= $1 \mathrm{C} 1 \mathrm{NNVC}$ enEG476EG476\&espv $=210 \& \mathrm{es}$ sm $=93 \& \mathrm{tbm}=$ isch\&tbo $=$ u\&source $=$ univ\&sa $=$ X\&ei $=\mathrm{gGsvU} 6$ fOCITPhAeAmoGgAg\&ved $=0$ CFQQsAQ\&biw $=1366 \&$ bih $=677$, on 5/3/2014

.(2014)."Images of Banners", Retrieved from: https://www.google.com.eg/search?q=Banners\&rlz=1C1NNVC_enE G476EG476\&espv $=210 \&$ es $s m=93 \&$ tbm $=$ isch\&tbo $=$ u\&source $=$ univ \&sa $=$ X\&ei=BS8vUnOOMjKhAedo4DIBQ\&ved=0CEoQsAQ\&biw $=$ $1366 \& b i h=677$, on $7 / 3 / 2014$ .(2014)."Banners' Activities", Retrieved from: https://www.google.com.eg/search?q=Banners $\% 27+$ Activi ties\&rlz=1C1NNVC enEG476EG476\&espv=210\&es sm= 93\&tbm=isch\&tbo=u\&source $=$ univ\&sa $=X \&$ ei $=g$ GsvU6fOCl TPhAeAmoGgAg\&ved=0CFQQsAQ\&biw=1366\&bih=677, on $8 / 3 / 2014$

- Google Search.(2014 ).Banners, Retrieved from:https://www. google.com.eg/search?q=Banners\&rlz=1C1NNVC_enEG476EG476\& espv $=210 \&$ es $s m=93 \&$ tbm $=$ isch\&tbo $=$ u\&source $=$ univ\&sa $=X \& e i=0$ GYvU4KNENLwhQf4IYGIBg\&ved $=0$ CEEQsAQ\&biw $=1366 \& b i h=6$ 77, on $8 / 3 / 2014$

- Guffey, Rhodes and Rogin.(2010) Business Communication: Process and Product. Third Brief Canadian Edition. Thomson-Nelson.

- Hairness, S.; Dallas,D.(2010). Hello! English for Secondary Schools, Year Two, Egyptian International Publishing Company- Longman.

- Gunelius, S. (2014)."What is a Blog?", Retrieved from: http:// weblogs.about.com/od/startingablog/p/WhatIsABlog.htm,on14/3/ 2014

$-$ .(2010). Hello! English for Secondary Schools, Year Two, Workbook, Egyptian International Publishing CompanyLongman.

- Henry, J. (2000). Writing workplace cultures: An archeology of professional writing. Carbondale, IL: Southern Illinois University Press.

- Hill, D. (2000) .Student Goal Orientation in a Writing Workshop Process Classroom and a Traditional Literacy Classroom. 
Unpublished PHD Dissertation, the University of North Carolina at Greensboro.

- Hywel, J. (2003). The Language Skills. (4th Ed Block A). Rawalpindi: Sigma Press. Allama Iqbal Open University Islamabad.

- Ibrahim, M.H.M. (2003).The Effect of Using a Program Based on Some Study Skills on Improving Secondary School First Graders' Writing, M.A. Thesis. Faculty of Education, Ain Shams University.

- Javed, M. ; Juan, W. X. ; Nazli, S. .(2013) A Study of Students' Assessment in Writing Skills of the English Language", in International Journal of Instruction, Vol.6, No.2e-ISSN: 1308-1470

- Johannessen, Larry R. (1995:1). "Teaching Descriptive/Narrative Writing: Strategies for Middle and Secondary Students", Retrieved from::http://eric.ed.gov/?id=ED379665, on 6/3/2014

- Jones, S. J. (2006: 7). Blogging and ESL Writing: a Case Study of How Students Responded to the Use of Weblogs as a Pedagogical Tool for the Writing Process Approach in a Community College ESL Writing Class. Ph.D., the University of Texas at Austin

- Kapka, D. \& Oberman, A. (2001). Improving Student Writing Skills through Modeling of the Writing Process. M. A. Project, Saint Xavier University and Skylight Professional Development Field-Based Master's Program.

- Lou, S.-J., et al.(2010). "Adoption of Blogging by a Chinese Language Composition Class in a Vocational High School in Taiwan", Australasian Journal of Educational Technology, V.26 N.6 PP. 898-916

- Marsden, N.; Piggot-I., E. (2012). "Using Blogging and Laptop Computers to Improve Writing Skills on a Vocational Training Course", in Australasian Journal of Educational Technology, V.28 N.1 PP. $30-47$

- Merriam-Webster Dictionary, (2014). "Definition of a Blog", Retrieved from: http://www.merriam-webster.com/dictionary/blog , on $10 / 3 / 2014$

- Miguel Bengoa elt.(2013)."English Language Teaching", Retrieved from:http://miguelbengoa.com/elt/?p=87, on 19/2/2014

- Moulton, J. (2008). "Blogs, Blogs Everywhere: Does Everyone Need an Internet Journal?" , Retrieved fromhttp://www.edutopia. org/blogging-purpose, on 22/2/2014 
- Mourad, A. E.(2009). "The Effectiveness of a Program Based on Self-Regulated Strategy Development on the Writing Skills of Writing-Disabled Secondary School Students", in Electronic Journal of Research in Educational Psychology, V.7 N.1 PP.5-24

- Muhammad J.; Xiao, J. W.; Saima. N.( 2013). "A Study of Students' Assessment in Writing Skills of the English Language", in International Journal of Instruction V.6, N.2 PP.129-144

- NCYE/TRA.(2004). "Read-Write-Think", Retrieved from:http:// www.readwritethink.org/files/resources/lesson images/lesson372/adv ice-rubric.pdf, on 25/2/2014

- Nordquist, R.(2014)."Writing Definition", Retrieved from: http:// grammar.about.com/od/tz/g/writingterm.htm, on 15/3/2014

- Newman \& Ober.(2013) "Business Communication: In Person, In Print, Online." South-Western, Retrieved from: http://en.wikipedia. org $/$ w/index.php?title $=$ Business_letter\&oldid $=596006987$

- O'Driscoll, A. (2009)." Junior Certificate English Higher Level Study Guide. Functional writing Guidelines and Sample Answers", Retrieved from :http://sacenglish.files.wordpress.com/2010/05/ functional- writing.pdf, on 12/2/2014

- Oxford Dictionary(2014)" Banner",Oxfrrd University Press, Retrieved from:http://www.oxforddictionaries.com/definition/ english banner

- Pesce, C.(2014:1-4)"10 Best Pieces of Advice You Could Ever Give Your ESL Students",Retrieved from:http://busyteacher.org/13132-10best-pieces-of-advice-esl-students.html, 18/2/2014

- Pylkkänen, L., \& McElree, B. (2006). The syntax-semantics interface: On-line composition of sentence meaning. Handbook of psycholinguistics, 2.

- Rap Genius Forum.(2014)."Common poster at my school library", Retrieved from: http://rapgenius.com/discussions/64158-Commonposter-at-my-school-library

- Rcampus (2014). "Business Letter Rubrics", Retrieved from: http://www.rcampus.com/rubricshowc.cfm?sp=yes\&code $=\mathrm{K} 68 \mathrm{~B} 4 \mathrm{~W}$ \&, on $18 / 2 / 2014$

- Richardson, W. (2006). Blogs, Wikis, Podcasts, and Other Powerful Tools for Classrooms. Thousand Oaks: Corwin Press. 
- Shahid, S. M. (1999). Teaching of English. Lahore: Majeed Book Depot.

- Roshaan,H.(2013)."What is Blogging, What is Blog and Who is Blogger", Retrieved from: http://blogginggame.com/what-isblogging-who-is-blogger-what-is-blog/, on 14/3/2014

- -RubiStar.(2006)."Read Write Think", Retrieved from: http://www. readwritethink.org/files/resources/lesson_images/lesson1076/rubric.p df, on 20/2/2014

- Scholastic.(2014)."Book Review", Retrieved from: https://www. scholastic.com/teachers/lessonplan/collateral_resources/pdf/r/review writing/books/book rubric.pdf

- SECME BANNER COMPETITION GUIDELINES. (2013)."BANNER COMPETITION REQUIREMENTS", Retrieved from:http://diversity. cecs.ucf.edu/download/2013\%20SECME\%20BANNER\%20Guidelin es.pdf, on $25 / 2 / 2014$

- Shin, Dong-S.(2009). "A Blog-Mediated Curriculum for Teaching Academic Genres in an Urban Classroom: Second Grade ELL Students' Emergent Pathways to Literacy Development", in ProQuest LLC, Ed.D. Dissertation, University of Massachusetts Amherst

- Sun, Y. \& Chang, Y. (2012). "Blogging to Learn: Becoming EFL Academic Writers Through Collaborative Dialogues.", in Language Learning \& Technology, 16(1), 43-61.

- Swaga, P.(2013)."The Magic of Functional Writing Skills", Rrtrievedfrom:http://www.newtimes.co.rw/news/index.php?i=15559 \&a $=17467 \&$ week $=48 \#$, on $21 / 2 / 2014$

- The Educational Company of Ireland. (2014). "Revise Wise English Junior Certificate- Higher Level. Study Guidelines. Functional Writing", Retrieved from: http://www.revisewise.ie/english/jc/pdfs/ functional-writing.pdf, on 22/2/2014

- The Tongue United (2008) "A guide to Grammar, Punctuation and Style", Retrieved from: http://www.grammaruntied.com/punctuation/ puncpracticeanswers.html

- University of Bristol, Faculty of Arts,(2012)" Improve Your Writing. Punctuation Marks Exercise." Retrieved from:http://www.bristol.ac. uk/arts/exercises/grammar/grammar tutorial/page 55.htm,on23/2/ 2014

- Vurdien, R. (2013) "Enhancing Writing Skills through Blogging in an Advanced English as a Foreign Language Class in Spain", in Computer Assisted Language Learning, V.26 N.2 PP.126-143

\section{4}


- Walters, P. (2013)."Activities for Functional Writing", Retrieved from http://www.ehow.co.uk/info 8144477 activities-functionalwriting.html, on 29/1/2014

- Wilcox, B. L. (2002). Thinking and Writing for Publication. New York: International Reading Association.

- Wren. P, C. \& Marten. H. (2006). High School English Grammar and Composition. New Delhi: S. Chand and Company Limited.

- Wu, H-J.; Wu, P.-L.(2011)."Learners' Perceptions on the Use of Blogs for EFL Learning", in US-China Education Review A 3 PP.323-330

العنوان : أثر استخدام المدونات بِّ تنمية بعض مهارات الكتابة الوظيفية لدى طلاب المئي

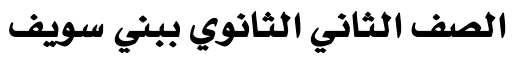

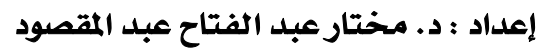

مدرس مناهج وطرق تدريس اللغة الإنجليزية بكلية التربية جامعة بني سويف

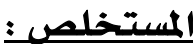

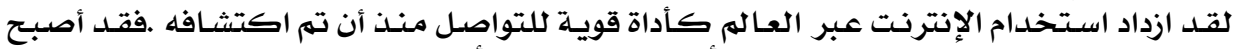

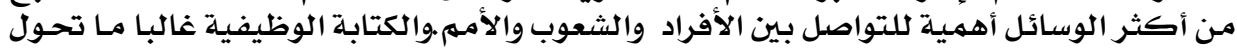

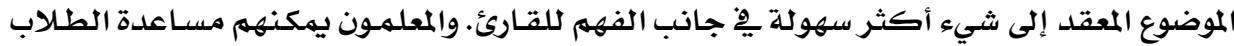

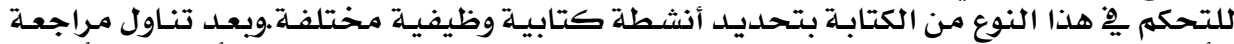

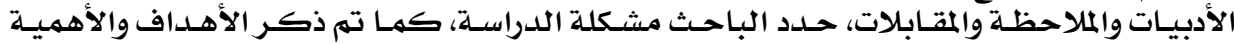

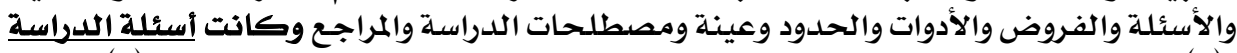

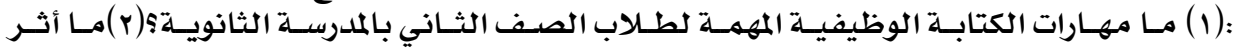

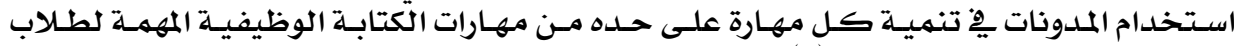

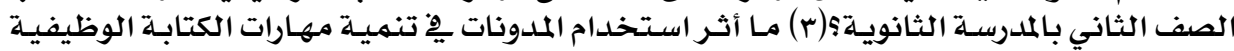

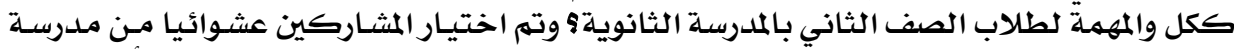

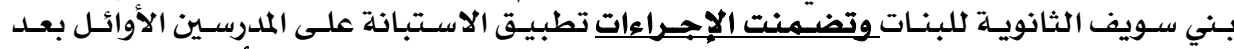

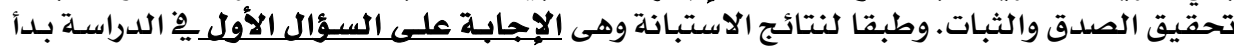

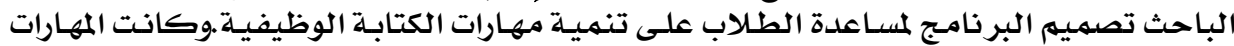

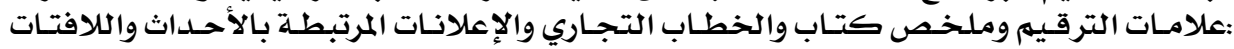

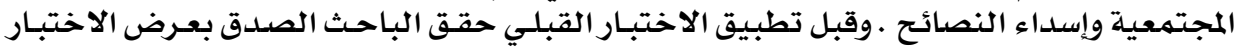

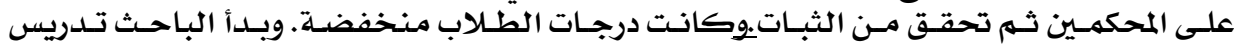

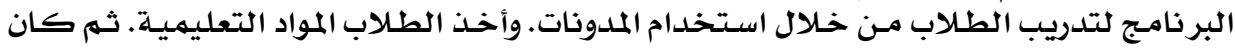

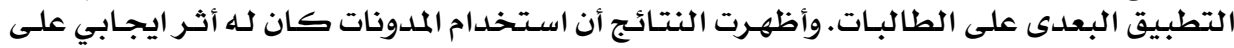
المهارات التابعة للكتابة البعلي الوظيفية الطبات

\section{楼潾潾潾}

